\title{
Radial Artery as a Graft for Coronary Artery Bypass Grafting
}

\author{
Junjiro Kobayashi, MD
}

\begin{abstract}
The radial artery (RA) graft was revived in late 1980s when it was found that the graft was patent 13-18 years after coronary artery bypass grafting (CABG) after improvement of the technique in harvesting and the use of calcium-channel blockers. Recently, the RA became a reasonable alternative to the saphenous vein (SV) graft with the trend toward complete arterial revascularization and more frequent off-pump CABG to avoid aortic manipulation. To improve the quality of the RA conduit, harvesting technique and topical and systemic antispasmodic medication are important. The RA should be grafted to severe proximal stenosis $(>90 \%)$ in the native coronary arteries to avoid flow competition, especially in the right coronary territory. The RA graft could be used as an aortocoronary or composite configuration with similar graft patency. Early graft patency of the RA conduit was as good as other arterial grafts, and better than SV graft in the circumflex and right coronary territories, in many studies, especially in diabetic patients. Long-term results of graft patency and cardiac-event-free survival compared with SV graft are still controversial in randomized controlled trials, probably because the incidence of flow competition and the definition of graft patency varied. (Circ J 2009; 73: 1178-1183)
\end{abstract}

Key Words: Coronary artery bypass; Left internal thoracic artery; Radial artery; Saphenous vein

$\mathbf{T}$ The superiority of the left internal thoracic artery (LITA) over the saphenous vein (SV) in coronary artery bypass grafting $(\mathrm{CABG})$ was widely accepted in angiographic studies in the $1980 \mathrm{~s}$ s,2 The clinical importance of the LITA to the left anterior descending artery (LAD) graft was emphasized in a long-term follow-up study comparing it with the SV over 20 years? The graft patency rate of the LITA to the LAD graft was approximately $90 \%$, and that of SV grafts was $50-60 \%$ at 10 years after CABG.,5 Because the SV developed intimal hyperplasia and graft atherosclerosis, which caused late graft occlusion, various arterial grafts have been adopted over the past 30 years. The right internal thoracic artery (RITA), 6,7 the right gastroepiploic artery (GEA),, 9 the radial artery (RA), ${ }^{10,11}$ and the inferior epigastric artery (IEA) ${ }^{12,13}$ have been used in addition to the LITA. According to the database of Japanese Association for Coronary Artery Surgery in 2004, the LITA comprised $37.5 \%$ of the total grafts. Other arterial grafts were $14.5 \%$ (RITA), $14.7 \%$ (RA), and 9.1\% (GEA). Arterial grafts accounted for $76 \%$ of total grafts in Japan, which is significantly higher than in Western countries. Here I review the current status of the RA graft as the second choice of arterial graft after the LITA.

\section{Historical Perspective}

The RA was first used in CABG by Carpentier et al in $1971 !^{14}$ However, 2 years later, they recommended not using the RA because of the $35 \%$ incidence of narrowing or occlusion of this conduit, which was much higher than in

(Received May 8, 2009; revised manuscript received May 11, 2009; accepted May 12, 2009; released online June 9, 2009)

Department of Cardiovascular Surgery, National Cardiovascular Center, Suita, Japan

Mailing address: Junjiro Kobayashi, MD, Department of Cardiovascular Surgery, National Cardiovascular Center, 5-7-1 Fujishiro-dai, Suita 565-8565, Japan. E-mail: jkobayas@hsp.ncvc.go.jp

All rights are reserved to the Japanese Circulation Society. For permissions, please e-mail: cj@j-circ.or.jp the SV graft by control angiography 15 Graft failure was caused by spasm and intimal hyperplasia after endothelial denudation from mechanical dilatation and the trauma of skeletonized harvesting. RA grafts were revived in late 1980 s when, after initially believing that they were occluded, they were found to be patent $13-18$ years after $\mathrm{CABG} !^{10}$ The technique of harvesting and the use of calcium-channel blockers has improved the early and late graft patency, and revived the use of the RA. The 5-year graft patency rate of the RA was $84 \%$ compared with $90 \%$ for the LITA. The study showed that the RA is a reasonable alternative to other graft materials that complement the LITA. Recently, the SV graft is being widely replaced by the RA. With the trend toward complete arterial revascularization and more frequent off-pump CABG (OPCAB) to avoid aortic manipulation, the use of the RA as a composite graft with the internal thoracic artery (ITA) has become more common!6,17

\section{Harvesting Technique}

The RA is easily harvested and has excellent handling characteristics. However, preoperative evaluation and proper harvesting technique is mandatory for good short- and longterm patency rates and the possibility of improved survival. The most widely used clinical test for assessment of adequate ulnar collateral circulation to the hand is the Allen test. Other assessment techniques, such as pulse oximetry, digital plethysmography, and Duplex scanning, have been reported ${ }^{18}$ Contraindications in addition to forearm ischemia are severe atherosclerosis with calcification, and dissection from prior cannulation. Thrombotic occlusion immediately before CABG because of preoperative cardiac catheterization is not a contraindication to use the RA after thrombectomy in the operating room. The most common complications after RA harvest are sensory abnormality and numbness, which occurs in $3-15 \%$ of patients. ${ }^{19,20}$

The options for RA harvest are pedicled or skeletonized with or without using the ultrasonic scalpel, and open vs endoscopic harvesting. Significantly greater blood flow is 
Table 1. Advantages and Disadvantages of the SV, RA, RITA, and GEA for CABG as a Second Graft to the LITA

\begin{tabular}{cll}
\hline \multicolumn{1}{c}{ Advantage } & \multicolumn{1}{c}{ Disadvantage } \\
\hline SV & Good handling & Poor short- and long-term patency \\
& Enough length for many anastomosis as for individual graft & Not available in varix patients \\
& Decreased transfusion than with bilateral ITA use & Postoperative leg edema \\
& Decreased harvesting time than with bilateral ITA use & Poorer wound healing than the RA \\
RA & Length $>20 \mathrm{~cm}$ & Very spasmodic \\
& Luminal diameter slightly larger than that of coronary arteries & Not always available \\
& Good handling & (Allen test positive, unsuitable quality, CRF) \\
& Decreased transfusion than with bilateral ITA use & Numbness and risk of motor dysfunction \\
DITA & Decreased harvesting time than with bilateral ITA use & Arm wound \\
& Excellent long-term patency & Longer harvesting time \\
& Less spastic than RA & Not graftable to PL or PDA as in-situ \\
& Almost always usable & More bleeding and sternal infection than with RA harvest \\
& Graftable to any territory as a composite free graft & Difficult handling as a composite graft \\
GEA & Thin arterial wall not suitable for aortic anastomosis \\
& Graftable to any territory as in-situ graft & Laparotomy (delayed oral intake) \\
& Substitute for RA composite graft & More spasmodic than the ITA \\
& Available in redo CABG & Not better than SV patency \\
& Suitable for MICS RCA anastomosis & Size variety not appropriate in some patients \\
\hline
\end{tabular}

SV, saphenous vein; RA, radial artery; RITA, right internal thoracic artery; GEA, gastroepiploic artery; CABG, coronary artery bypass grafting; LITA, left internal thoracic artery; ITA, internal thoracic artery; CRF, chronic renal failure; PL, posterolateral branch; PDA, posterior descending artery; MICS, minimally invasive cardiac surgery; RCA, right coronary artery.

reported in RA grafts harvested by ultrasonic scalpel than in traditionally harvested RA grafts ${ }^{21}$ probably because of the larger RA caliber with the skeletonizing technique and better pharmacological preparation. In addition to systemic administration of nitroglycerin and diltiazem, antispasmodic agents are used topically. Papaverine, which is a short-acting phosphodiesterase inhibitor, is a widely used vasodilator for ITA and RA harvesting. As it is very acidic, a mixture of blood as a buffer is mandatory when it is infused into the lumen of the RA. Milrinone, which is a long-acting phosphodiesterase inhibitor, systemically used for heart failure as a dilator, has been administered intraluminally to prevent RA spasm, with good clinical results? ${ }^{2}$ Verapamil and nitroglycerin (VG solution) can effectively prevent spam against a wide range of vasoconstrictors, with better preservation of endothelial function than papaverine ${ }^{23}$ The alpha-adrenoreceptor antagonist, phenoxybenzamine, and verapamil in heparinized blood are also used intraluminally and topically?

\section{Advantage of RA Use}

In Western countries, conventional CABG consists of LITA to the LAD and SV grafts to other coronary branches under cardiac arrest with cardiopulmonary bypass. Despite the easy access and adequate length for aortocoronary bypass, SV grafts have poor long-term patency. ${ }^{3-5}$ In any patient category, bilateral ITA use has been reported as better than only LITA use in late clinical results. ${ }^{25-27}$ However, bilateral ITA harvesting has shown a higher incidence of sternal wound infection in patients taking insulin or steroids, who are obesity or have chronic obstructive lung disease?28,29 In addition, the RITA to LAD graft crossing the midline of the chest may obstruct future reoperations for aortic valve surgery, but to avoid this situation the RITA is unable to reach the posterolateral coronary artery even if it passes through the transverse sinus.

The RA is more than $20 \mathrm{~cm}$ in length on average and able to reach any coronary territory when it is used as a composite graft. The RA has an inner diameter of $2-3 \mathrm{~mm}$ without size mismatch to the coronary arteries. Harvesting of the RA is concurrently possible with LITA and SV harvesting. There are several observational studies that showed better early and late mortality and morbidity compared with SV grafts 30,31 Unlike the SV grafts, the RA grafts adapted to arterial pressure and flow, and changed diameter for optimal flow velocity. As the second arterial graft in addition to LITA to LAD anastomosis, cohort studies comparing the RITA and the RA showed the same clinical and angiographic results 32,33 In addition, perioperative bleeding and sternal wound infection are favorable with the RA compared with the RITA 33

Other arterial grafts have their own disadvantages. The GEA, which is able to reach any coronary territory as an in-situ graft, has been widely used in Japan compared with Western countries. Use of in-situ GEA for CABG was first reported in 1987, and early graft patency ranged from $90 \%$ to $100 \% \%^{8} 9$ Long-term graft patency at 10 years was not better than with SV grafts, ${ }^{34}$ probably because of the size variation. GEA harvesting requires a longer skin incision and laparotomy, which delays oral intake. The GEA is also prone to flow competition compared with the LITA because the GEA is the third branch of the abdominal aorta and has $10-15 \mathrm{mmHg}$ lower pressure at its end compared with the end of the LITA ${ }^{35-37}$ Although skeletonized and composite use of the GEA for larger internal diameter and flow has been reported 38 avoiding flow competition has not been proved $39-41$

The IEA was first reported as an alternative arterial graft to the SV in $1990 !^{12}$ It is relatively short and only suitable for grafting to diagonal or intermediate branches. The major complication of IEA harvesting is abdominal wall hematoma or infection. As the graft patency of the IEA is not better than SV grafts, it is no longer used widely.

\section{Disadvantages of RA Use}

One of disadvantages of the RA is the intense spasm. Basic study has delineated that the mechanism of severe spasm in the RA is more difficult to reverse compared with the LITA ${ }^{42}$ The functioning of the RA in releasing endothelium-derived relaxing factors such as nitric oxide is the same 
Table 2. Patency Rate of RA and Other Grafts

\begin{tabular}{|c|c|c|c|c|c|c|c|c|c|}
\hline Reference & Year & Interval & RA & $\%$ of $\mathrm{AC}$ & LITA & RITA & GEA & IEA & SV \\
\hline \multirow[t]{2}{*}{ Acar $^{10}$} & 1992 & $<3$ weeks & $56 / 56(100 \%)$ & $100 \%$ & $48 / 48(100 \%)$ & $11 / 11(100 \%)$ & & & $8 / 9(88.9 \%)$ \\
\hline & & 9.2 months & $29 / 31(93.5 \%)$ & & $28 / 28(100 \%)$ & $9 / 9(100 \%)$ & & & \\
\hline \multirow{2}{*}{ Calafiore $^{55}$} & 1995 & 3.6 months & $75 / 76(98.7 \%)$ & $0 \%$ & & & & $67 / 70(95.7 \%)$ & \\
\hline & & 21.2 months & $33 / 35(94.3 \%)$ & & & & & $25 / 25(100 \%)$ & \\
\hline da Costa ${ }^{56}$ & 1996 & 8.7 months & $59 / 61(96.7 \%)$ & $100 \%$ & $21 / 32(96.8 \%)$ & $12 / 13(92.3 \%)$ & $1 / 1(100 \%)$ & & $13 / 14(92.8 \%)$ \\
\hline Brodman $^{57}$ & 1996 & 11.9 weeks & $86 / 90(95.5 \%)$ & $100 \%$ & & & & & \\
\hline Chen 58 & 1996 & 11.6 weeks & $90 / 94(95.7 \%)$ & $100 \%$ & $62 / 62(100 \%)$ & & & & $22 / 24(93.3 \%)$ \\
\hline Possati ${ }^{59}$ & 1998 & 59 months & $57 / 62(91.9 \%)$ & $100 \%$ & $57 / 58(98.2 \%)$ & $3 / 4(75 \%)$ & $9 / 10(90 \%)$ & & $43 / 58(74.1 \%)$ \\
\hline Tatoulis $^{60}$ & 1998 & 4.2 months & $21 / 22(95.7 \%)$ & $90 \%$ & $16 / 16(100 \%)$ & & & & \\
\hline Acar $^{61}$ & 1998 & 5.6 years & $54 / 64(84.4 \%)$ & $100 \%$ & $44 / 47(93.6 \%)$ & & & & \\
\hline Bhan $^{62}$ & 1999 & 16.2 months & $60 / 62(96.8 \%)$ & $100 \%$ & $56 / 57(98.2 \%)$ & & & & \\
\hline \multirow[t]{2}{*}{ Amano ${ }^{63}$} & 2001 & $<3$ months & $137 / 139(98.6 \%)$ & $69 \%$ & $99 / 100(99.0 \%)$ & $27 / 27(100 \%)$ & $48 / 50(96.0 \%)$ & & $34 / 38(89.5 \%)$ \\
\hline & & 1.5 years & $213 / 229(93.0 \%)$ & $65 \%$ & $168 / 171(98.2 \%)$ & $27 / 27(100 \%)$ & $75 / 82(91.4 \%)$ & & $71 / 79(89.8 \%)$ \\
\hline \multirow[t]{2}{*}{ Iacò 64} & 2001 & 18 days & $88 / 89(98.9 \%)$ & $11 \%$ & $82 / 82(100 \%)$ & & 13/13 (100\%) & 12/12 (100\%) & $4 / 4(100 \%)$ \\
\hline & & 48 months & $87 / 91(95.6 \%)$ & $22 \%$ & $63 / 93(100 \%)$ & & $11 / 12(91.7 \%)$ & $10 / 11(90.9 \%)$ & $8 / 9(88.8 \%)$ \\
\hline Possati 65 & 2003 & 105 months & $77 / 84(91.6 \%)$ & $100 \%$ & $80 / 82(97.5 \%)$ & $6 / 7(85.7 \%)$ & $14 / 15(93.3 \%)$ & & $39 / 73(53.4 \%)$ \\
\hline Cameron ${ }^{66}$ & 2004 & 5.2 years & $55 / 62(88.7 \%)$ & $96 \%$ & $51 / 51(100 \%)$ & $17 / 18(94.4 \%)$ & & & $33 / 36(91.6 \%)$ \\
\hline Zacharias 67 & 2004 & 1.8 years & $111 / 157(70.7 \%)$ & NA & $370 / 394(93.9 \%)$ & & & & $95 / 161(59.0 \%)$ \\
\hline $\operatorname{Khot}^{68}$ & 2004 & 565 days & $204 / 398(51.3 \%)$ & NA & $243 / 269(90.3 \%)$ & $61 / 77(79.2 \%)$ & & & $174 / 272(64.0 \%)$ \\
\hline
\end{tabular}

IEA, inferior epigastric artery; AC, aortocoronary bypass; NA, not available. Other abbreviations see in Table 1.

as for other arterial grafts, as is its constriction function to vasoconstrictive factors. However, the RA has multiple tight muscle layers in the media, which has a higher density of muscle cells than other arterial grafts. Because of this, the RA wall has a higher maximum contractile force in response to vasoconstrictive agents, such as norepinephrine, serotonin, endothelin I, and angiotensin II. These chemical mediators are released after endothelial damage caused by surgical trauma and platelet aggregation.

RA grafts frequently show the flow competition phenomenon with mildly stenotic native coronary arteries ${ }^{43-51}$ The use of the RA in composite grafts with the LITA as Y or T grafts showed similar graft patency as RA grafts used as an aortocoronary bypass ${ }^{4-47}$ However, Gaudino et al found flow competition more frequently in the composite RA conduits than in the aortocoronary RA conduit ${ }^{8}$ Long-term patency of these competitive RA grafts was poor by angiographic analysis, though it was better than the SV when good forward flow was present ${ }^{44,49,50}$ Other potential disadvantages of composite grafts compared with aortocoronary grafts are the relative technical difficulty and the reliance of a single inflow to supply all or many coronary territories 51 The SV graft still has a role as a graft to the moderately stenotic right coronary territory because of the high incidence of flow competition of composite RA grafts to the right coronary branches, $11,43,44,47,51,52$ and the poor early graft patency of the RITA to the right coronary artery 33,54 The advantage and disadvantage of the grafts are listed in Table 1.

\section{Patency of RA Grafts}

The long-term outcome after CABG depends on graft patency. Previous angiographic observational studies have shown that the RA achieved excellent short- (96-100\%), mid- (94-97\%), and long-term graft patency (84-96\%) when used as either an aortocoronary bypass or a composite graft (Table 2)! ${ }^{10,55-67}$ Patency rates of the RA have exceeded those of SV grafts at all time points and are comparable to other arterial grafts. Many reports have shown better outcomes of the RA compared with the SV $10,56,58,59,63-65,67$ though some reported similar long-term graft patency $33,45,48,66$
Only the Cleveland Clinic reported worse graft patency of the RA than the SV 68

Possati et al reported the long-term (105 \pm 9 months) graft patency of RA grafts in a series of 90 consecutive CABG patients.5 ${ }^{65}$ The RA graft patency was $88 \%$, which was less than that of the LITA (96\%), but better than that of the SV $(53 \%)$. Although these results are encouraging the use of the RA as a complementary arterial conduit with the LITA, there are only a few long-term studies assessing RA graft patency in the setting of a randomized controlled trial.

\section{Randomized Controlled Trials}

The Radial Artery Patency Study (RAPS) Investigators enrolled 561 patients in 13 centers ${ }^{69}$ In this trial, the RA graft was randomly assigned to bypass the major artery in either the right coronary territory or the circumflex coronary territory, with the SV graft used for the opposing territory, which had proximal lesions at least 70\% diameter narrowing. Angiography for 440 RA grafts and 440 SV grafts was performed in 440 patients in 1 year. Desai et al reported that $8.2 \%$ of RA grafts and $13.6 \%$ of SV grafts were completely occluded $(\mathrm{P}=0.009){ }^{69}$ Diffuse narrowing of the graft (string sign) was present in $7.0 \%$ of the RA grafts and only $0.9 \%$ of SV grafts $(\mathrm{P}=0.001)$. The absence of severe native vessel stenosis was a risk of graft occlusion and diffuse narrowing of the RA conduit (70-89\% proximal stenosis: $81.7 \%$; $>90 \%$ proximal stenosis: $91.5 \%$ ). Patency of the RA grafts was similar in the right coronary and circumflex arteries. These results are compatible with previous reports suggesting that the RA should be limited to grafting to native coronary vessels with a high degree of stenosis $(>70 \%)$ because of graft sensitivity to competitive flow and diffuse narrowing $4{ }^{4-51}$ Diffuse narrowing of the RA graft is thought to be of little or no clinical consequence because the narrowed graft may improve or work well late in the follow-up. However, cardiologists consider the string sign of the RA graft as a failure. As the string sign at 1 year is unfavorable toward a functioning RA or SV graft, $15.2 \%$ of RA grafts and $14.5 \%$ of SV grafts are occluded or functioning poorly. In an early postoperative study, composite RA grafts with competitive flow without diffuse narrowing were present in $7.3 \%$ of 
total conduits ${ }^{70}$ The actuarial patency rate of these grafts on late angiography was only $33.9 \%$ at 3 years after OPCAB. RA grafting should not be considered in the setting of $<75 \%$ proximal coronary obstruction, especially in the right coronary branches.

The RAPS Investigators also reported that diabetes (RR: 1.45, $\mathrm{P}=0.03$ ), female gender ( $\mathrm{RR}: 1.78, \mathrm{P}=0.02)$, and small target vessel diameter (RR: $2.28, \mathrm{P}<0.01)$ are multivariate predictors of graft failure?1,72 Graft occlusion was more common among diabetic patients (14\% vs $10 \%)$ because of more frequent SV occlusion (19\%) than RA occlusion $(10 \%)$. The RA is protective in the small-sized coronary arteries with diffuse diabetic disease. With regard to gender, RA graft occlusion rate at 1 year was similar in men (8.6\%) and women $(5.3 \%)(\mathrm{P}=0.6)$, whereas $\mathrm{SV}$ graft occlusion rates were lower in men $(12.0 \%)$ than in women $(23.3 \%)$. A history of peripheral vascular disease was associated with an elevated risk of RA occlusion, but not with SV occlusion. On the contrary, angiographic studies of patients at the Cleveland Clinic found poor graft patency in the RA (51\%) compared with the SV (64\%). With regard to sex, women had significantly worse RA graft patency $(39 \%)$ than men $(56 \%) 67$

The Radial Artery Patency and Clinical Outcome (RAPCO) study was undertaken to compare angiographic patency and cardiac-event-free survival of the RA graft with that of the free RITA and SV during a 10 -year period after CABG ${ }^{73}$ The RA was compared with the free RITA in patients $<70$ years of age and with the SV in patients aged $>75$ years. The 5-year interim results of this single center trial conducted by Buxton et al in Australia reported that there were no differences in angiographic graft failure and cardiac events of the patients with the RA compared with the RITA or SV. The 5-year patency rates between the RA and RITA were $95 \%$ vs $100 \%$, respectively, and those between the RA and SV were $87 \%$ vs $94 \%$. However, these results were based on a small number of angiographic studies, and SV graft patency was very much better than in previous reports. The final results up to 10 years should clarify the long-term RA graft patency.

The Radial Artery Versus Saphenous Vein Graft Patency (RSVP) trial was a single-center, prospective, randomized clinical trial designed to compare 5-year patency rates of RA and SV aortocoronary grafts to the circumflex coronary artery? ${ }^{4}$ At 5 years, 103 patients among 142 enrolled patients underwent angiography. The graft patency of the RA $(98.3 \%)$ was significantly $(\mathrm{P}=0.04)$ better than that of the SV $(86.4 \%)$. Graft narrowing occurred in $10 \%$ of patent RA grafts and $23 \%$ of $\mathrm{SV}$ grafts $(\mathrm{P}=0.01)$.

Total arterial myocardial revascularization with a composite RITA or RA was compared with conventional CABG in a prospective randomized fashion by Muneretto et al? ${ }^{75}$ At a mean follow-up of 12 months, the total arterial CABG group had a better outcome in terms of angina recurrence, need for percutaneous cardiac intervention, and actuarial freedom from cardiac events. The 1-year results for total arterial revascularization, in which the RA was used as a composite or aortocoronary conduit in addition to in-situ bilateral ITA grafting, vs conventional coronary CABG (CARRPO trial) showed similar graft patency, and cardiacevent-free rates at 1 year after $\mathrm{CABG}$ ? $^{76}$

\section{Summary and Recommendation}

To improve the quality of the RA conduit, harvesting technique and topical and systemic antispasmodic medication are important. The RA should be grafted to severe proximal stenosis $(>90 \%)$ in the native coronary arteries to avoid flow competition. The RA graft can be used as an aortocoronary or composite configuration with the same graft patency. Early graft patency of the RA conduit is as good as other arterial grafts and better than the SV graft in the circumflex and right coronary territories in many studies, especially in diabetic patients. Long-term results of graft patency and cardiac-event-free survival compared with SV graft are still controversial in randomized controlled trials, probably because both the incidence of flow competition and the definition of graft patency varied.

\section{References}

1. Loop FD, Lytle BW, Cosgrove DM, Stewart RW, Goormastic M, William GW, et al. Influence of the internal mammary artery graft on 10-year survival and other cardiac events. $N$ Engl J Med 1986; 314: $1-6$.

2. Lytle BW, Loop FD, Cosgrove DM, Ratliff NB, Easley K, Taylor PC. Long-term (5 to 12 years) serial studies of internal mammary artery and saphenous vein coronary artery bypass grafts. $J$ Thorac Cardiovasc Surg 1985; 89: 248-258.

3. Boylan MJ, Lytle BW, Loop FD, Taylor PC, Borsh JA, Goormastic $\mathrm{M}$, et al. Surgical treatment of isolated left anterior descending coronary stenosis: Comparison of the left internal mammary artery and venous autograft at 18 to 20 years of follow up. J Thorac Cardiovasc Surg 1994; 107: 657-662.

4. Bourassa MG, Fischer LD, Campeau L, Gillespie MJ, McConney M, Lespérance J. Long-term fate of bypass graft: The Coronary Artery Surgery Study (CASS) and Montreal Heart Institute experience. Circulation 1985; 6(Suppl V): V-71-V-78.

5. Ura M, Sakata R, Nakayama Y, Arai Y, Saito T. Long-term results of bilateral internal thoracic artery grafting. Ann Thorac Surg 2000; 70: $1991-1996$.

6. Ioannidis JP, Galanos O, Katritsis D, Connery CP, Drossos GE, Swistel DG, et al. Early mortality and morbidity of bilateral versus single internal thoracic artery revascularization: Propensity and risk modeling. J Am Coll Cardiol 2001; 37: 521-528.

7. Tector AJ, Mc Donald ML, Kress DC, Downey FX, Schmahl TM. Purely internal thoracic artery grafts: Outcomes. Ann Thorac Surg 2001; 72: 450-455.

8. Suma H, Fukumoto H, Takeuchi A. Coronary artery bypass grafting by utilizing in situ right gastroepiploic artery: Basic study and clinical application. Ann Thorac Surg 1987; 44: 394-397.

9. Mills NL, Everson CT. Right gastroepiploic artery: A third arterial conduit for coronary bypass. Ann Thorac Surg 1989; 47: 706-711.

10. Acar C, Jebara VA, Portoghese M, Beyssen B, Pagny JY, Grare P, et al. Revival of the radial artery for coronary artery bypass grafting. Ann Thorac Surg 1992; 54: 652-660.

11. Tatoulis J, Royse AG, Buxton BF, Fuller JA, Skillington PD, Goldblatt JC, et al. The radial artery in coronary surgery: A 5-year experience-clinical and angiographic results. Ann Thorac Surg 2002; 73: $143-148$.

12. Vincent JG, van Son JAM, Skotnicki SH. Inferior epigastric artery as a conduit in myocardial revascularization: The alternative free arterial graft. Ann Thorac Surg 1990; 49: 323-325.

13. Perrault LP, Carrier M, Hebert Y, Cartier R, Leclerc Y, Pelletier LC. Early experience with the inferior epigastric artery in coronary artery bypass grafting: A word of caution. J Thorac Cardiovasc Surg 1993; 106: $928-930$.

14. Carpentier A, Guermonprez JL, Deloche A, Frechette C, DuBost C. The aorta-to-coronary radial artery bypass graft: A technique avoiding pathological changes in grafts. Ann Thorac Surg 1973; 16: 111 121.

15. Curtis JJ, Stoney WS, Alford WC Jr, Burrus GR, Thomas CS Jr. Intimal hyperplasia: A cause of radial artery aortocoronary bypass graft failure. Ann Thorac Surg 1975; 20: 628-635.

16. Kobayashi J, Tagusari O, Bando K, Niwaya K, Nakajima H, Ishida $\mathrm{M}$, et al. Total arterial off-pump coronary revascularization with only ITA and composite radial artery grafts. Heart Surg Forum 2002; 6: 30-37.

17. Tagusari O, Kobayashi J, Bando K, Niwaya K, Nakajima H, Ishida $\mathrm{M}$, et al. Total arterial off-pump coronary artery bypass grafting for revascularization of the total coronary system: The clinical outcome and angiographic evaluation. Ann Thorac Surg 2004; 78: 1304-1311. 
18. Abu-Omar Y, Mussa S, Anastasiadis K, Steel S, Hands L, Taggart DP. Duplex ultrasonography predicts safety of radial artery harvest in the presence of an abnormal Allen test. Ann Thorac Surg 204; 77: $116-119$.

19. Greene MA, Malias MA, Fuller JA. Arm complications after radial artery procurement for coronary bypass operation. Ann Thorac Surg 2001; 72: $126-128$

20. Budillon AM, Nicolini F, Agostnelli A, Beghi C, Pavesi G, Fragnito $\mathrm{C}$, et al. Complications after radial artery harvesting for coronary artery bypass grafting: Our experience. Surgery 2003; 133: 283-287.

21. Ronan JW, Perry LA, Barner HB, Sundt TM III. Radial artery harvest: Comparison of ultrasonic dissection with standard technique. Ann Thorac Surg 2000; 69: 113-114.

22. He GW, Yang CQ. Vasorelaxant effect of phosphodiesterase-inhibitor milrinone in the human radial artery used as coronary bypass graft. J Thorac Cardiovasc Surg 2000; 119: 1039-1045.

23. He GW, Yang CQ. Use of verapamil and nitroglycerin solution in preparation of radial artery coronary bypass grafting. $J$ Thorac Cardiovasc Surg 1996; 61: 610-614.

24. Mussa S, Guzik TJ, Black E, Dipp MA, Channon KM, Taggart DP Comparative efficacies and durations of action of phenoxybenzamine, verapamil/nitroglycerin solution, and papaverine as topical antispasmodics for radial artery coronary bypass grafting. $J$ Thorac Cardiovasc Surg 2003; 126: 1789-1805.

25. Endo M, Nishida H, Tomizawa Y, Kasanuki H. Benefit of bilateral over single internal mammary artery grafts for multiple coronary artery bypass grafting. Circulation 2001; 104: 2164-2170.

26. Berreklouw E, Rademakers PP, Koster JM, van Leur L, van der Wielen BJ, Westers P. Better ischemic event-free survival after two internal thoracic artery grafts: 13 years of follow-up. Ann Thorac Surg 2001; 72: $1535-1541$

27. Stevens LM, Carrier M, Perrault LP, Hébert Y, Cartier R, Bouchard $\mathrm{D}$, et al. Single versus bilateral internal thoracic artery grafts with concomitant saphenous vein grafts for multivessel coronary artery bypass grafting: Effects on mortality and event-free survival. J Thorac Cardiovasc Surg 2004; 127: 1408-1415.

28. Grossi EA, Esposito R, Harris LJ, Crooke GA, Galloway AC, Colvin $\mathrm{SB}$, et al. Sternal wound infections and use of internal mammary artery grafts. J Thorac Cardiovasc Surg 1991; 102: 342-347.

29. Matsa M, Paz Y, Gurevich J, Shapira I, Kramer A, Pevny D, et al Bilateral skeletonized internal thoracic artery grafts in patients with diabetes mellitus. J Thorac Cardiovasc Surg 2001; 121: 668-674.

30. Cohen G, Tamariz MG, Sever JY, Liaghati N, Guru V, Christakis GT, et al. The radial artery versus the saphenous vein graft in contemporary CABG: A case match study. Ann Thorac Surg 2001; 71: 180186.

31. Zacharias A, Habib RH, Schwann TA, Riordan CJ, Durham SJ, Shah A. Improved survival with radial artery versus vein conduits in coronary bypass surgery with left internal thoracic artery to left anterior descending artery grafting. Circulation 2004; 109: 1489-1496.

32. Calafiore AM, Di Mauro M, D’Alessandro S, Teodori G, Vitolla G, Contini M, et al. Revascularization of the lateral wall: Long-term angiographic and clinical results of radial artery versus right internal thoracic artery grafting. J Thorac Cardiovasc Surg 2002; 123: $225-$ 231 .

33. Lemma M, Gelpi G, Mangini A, Vanelli P, Carro C, Condemi A, et al. Myocardial revascularization with multiple arterial grafts: Comparison between the radial artery and the right internal thoracic artery. Ann Thorac Surg 2001; 71: 1969-1973.

34. Suma H, Tanabe H, Takahashi A, Horii T, Isomura T, Hirose H, et al Twenty year experience with the gastroepiploic artery graft for CABG. Circulation 2007; 116(Suppl I): I-188-I-191.

35. Hashimoto H, Isshiki T, Ikari Y, Hara K, Saeki F, Tamura T, et al. Effect of competitive blood flow on arterial graft patency and diameter: Medium-term postoperative follow-up. J Thorac Cardiovasc Surg 1996; 111: 399-407.

36. Shimizu T, Suesada H, Cho M, Ito S, Ikeda K, Ishimaru S. Flow capacity of gastroepiploic artery versus vein grafts for intermediate coronary artery stenosis. Ann Thorac Surg 2005; 80: 124-130.

37. Ochi M, Hatori N, Fujii M, Saji Y, Tanaka S, Honma H. Limited flow capacity of the right gastroepiploic artery graft: Postoperative echocardiographic and angiographic evaluation. Ann Thorac Surg 2001 71: $1210-1214$

38. Suma H, Tanabe H, Yamada J, Mikuriya A, Horii T, Isomura T. Midterm results for use of the skeletonized gastroepiploic artery graft in coronary artery bypass. Circ $J$ 2007; 71: 1503-1505.

39. Asai T, Tabata S. Skeletonization of the right gastroepiploic artery using an ultrasonic scalpel. Ann Thorac Surg 2002; 74: 1715-1717.

40. Gagliardotto P, Coste P, Lazreg M, Dor V. Skeletonized right gastroepiploic artery used for coronary artery bypass grafting. Ann Thorac
Surg 1998; 66: 240-242

41. Amano A, Li R, Hirose H. Off-pump coronary artery bypass using skeletonized gastroepiploic artery, a pilot study. Heart Surg Forum 2004; 7: $101-104$

42. Verma S, Szmitko PE, Weisel RD, Bonneau D, Latter D, Errett L, et al. Should radial arteries be used routinely for coronary artery bypass grafting? Circulation 2004; 110: e40-e46.

43. Royse AG, Royse CF, Ttoulis J, Grigg LE, Shah P, Hunt D, et al. Postoperative radial artery angiography for coronary artery bypass surgery. Eur J Cardiothorac Surg 2000; 17: 294-304.

44. Nakajima H, Kobayashi J, Tagusari O, Bando K, Niwaya K, Kitamura S. Competitive flow in arterial composite grafts and effect of graft arrangement in off-pump coronary revascularization. Ann Thorac Surg 2004; 78: $481-486$.

45. Lemma M, Mangini A, Gelpi G, Innorta A, Spina A, Antona C. Is it better to use radial artery as a composite graft? Clinical and angiographic results of aorta-coronary versus Y-graft. Eur J Cardiothorac Surg 2004; 26: 110-117.

46. Yie K, Na C, Oh SS, Kim J, Shinn S, Seo H. Angiographic results of the radial artery graft patency according to the degree of native coronary stenosis. Eur J Cardiothorac Surg 2008; 33: 341-348.

47. Maniar HS, Barner HB, Bailey MS, Prasad SM, Moon MR, Pasque MK, et al. Radial artery patency: Are aortocoronary conduits superior to composite grafting? Ann Thorac Surg 2003; 76: 1498-1504.

48. Gaudino M, Alessandrini F, Pragliola C, Cellini C, Glieca F, Luciani $\mathrm{N}$, et al. Effect of target artery location and severity of stenosis on midterm patency of aorta-anastomosed vs internal artery-anastomosed radial artery grafts. Eur J Cardiothorac Surg 2004; 25: 424-428.

49. Nakajima H, Kobayashi J, Tagusari O, Niwaya K, Funatsu T, Kawamura A, et al. Angiographic flow grading and graft arrangement of arterial conduits. J Thorac Cardiovasc Surg 2006; 132: 10231029 .

50. Nakajima H, Kobayashi J, Tagusari O, Bando K, Niwaya K, Kitamura S. Functional angiographic evaluation of individual, sequential, and composite arterial grafts. Ann Thorac Surg 2006; 81: 807-814.

51. Maniar HS, Sundt TM, Barner HB, Prasad SM, Peterson L, Absi T, et al. Effect of target stenosis and location on radial artery graft patency. J Thorac Cardiovasc Surg 2002; 123: 45-52.

52. Légaré JF, Buth KJ, Sullivan JA, Hirsch GM. Composite arterial grafts versus conventional grafting for coronary artery bypass grafting. J Thorac Cardiovasc Surg 2004; 127: 160-166.

53. Shah PJ, Durairaj M, Gordon I, Fuller J, Rosalion A, Seevanayagam $\mathrm{S}$, et al. Factors affecting patency of internal thoracic artery graft: Clinical and angiographic study in 1434 symptomatic patients operated between 1982 and 2002. Eur J Cardiothorac Surg 2004; 26: $118-124$.

54. Shah PJ, Bui K, Blackmore S, Gordon I, Hare DL, Fuller J, et al. Has the in situ right internal thoracic artery been overlooked? An angiographic study of the radial artery, internal thoracic arteries and saphenous vein graft patencies in symptomatic patients. Eur J Cardiothorac Surg 2005; 27: 870-875.

55. Calafiore AM, Di Giammarco G, Teodori G, D’Annunzio E, Vitolla G, Fino C, et al. Radial artery and inferior epigastric artery in composite grafts: Improved midterm angiographic results. Ann Thorac Surg 1995; 60: $517-523$.

56. da Costa FD, da Costa IA, Poffo R, Abuchaim D, Gaspar R, Garcia L et al. Myocardial revascularization with the radial artery: A clinical and angiographic study. Ann Thorac Surg 1996; 62: 475-480.

57. Brodman RF, Frame R, Camacho M, Hu E, Chen A, Hollinger I, et al. Routine use of unilateral and bilateral radial arteries for coronary artery bypass graft surgery. J Am Coll Cardiol 1996; 28: 959-963.

58. Chen AH, Nakao T, Brodman RF, Greenberg M, Charney R, Menegus $\mathrm{M}$, et al. Early postoperative angiographic assessment of radial artery grafts used for coronary artery bypass grafting. J Thorac Cardiovasc Surg 1996; 111: $1208-1212$

59. Possati G, Gaudino M, Alessandrini F, Luciani N, Glieca F, Trani C, et al. Midterm clinical and angiographic results of radial artery grafts used for myocardial revascularization. J Thorac Cardiovasc Surg 1998; 116: $1015-1021$.

60. Tatoulis J, Buxton BF, Fuller JA. Bilateral radial artery grafts in coronary reconstruction: Technique and early results in 261 patients. Ann Thorac Surg 1998; 66: 714-720.

61. Acar C, Ramsheyi A, Pagny J, Jebara V, Barrier P, Fabiani J, et al. The radial artery for coronary artery bypass grafting: Clinical and angiographic results at five years. J Thorac Cardiovasc Surg 1998; 116: $981-989$.

62. Bhan A, Guppa V, Choudhary SK, Sharma R, Singh B, Aggarwal R, et al. Radial artery in CABG: Could the early results be compatible to internal mammary artery graft? Ann Thorac Surg 1999; 67: 16311636. 
63. Amano A, Hirose H, Takahashi A, Nagano N. Coronary artery bypass grafting using the radial artery: Midterm results in Japanese institute. Ann Thorac Surg 2001; 72: 120-125.

64. Iacò AL, Teodori G, Di Giammarco G, Di Mauro M, Storto L, Mazzei $\mathrm{V}$, et al. Radial artery for myocardial revascularization: Long-term clinical and angiographic results. Ann Thorac Surg 2001; 72: 464469.

65. Possati G, Gaudino M, Prati F, Alessandrini F, Trani C, Glieca F, et al. Long-term results of the radial artery used for myocardial revascularization. Circulation 2003; 108: 1350-1354.

66. Cameron J, Trivedi S, Stafford G, Bett JH. Five-year angiographic patency of radial artery bypass grafts. Circulation 2004; 110(Suppl II): II- $23-$ II- 26 .

67. Zacharias A, Habib RH, Schwann TA, Riordan CJ, Durham SJ, Shah A. Improved survival with radial artery versus vein conduit in coronary bypass surgery with left internal thoracic artery to left anterior descending artery graft. Circulation 2004; 109: 1489-1496.

68. Khot UN, Friedman DT, Pettersson G, Smedira NG, Li J, Ellis SG Radial artery bypass grafts have an increased occurrence of angiographically severe stenosis and occlusion compared with left internal mammary arteries and saphenous vein grafts. Circulation 2004; 109: 2086-2091.

69. Desai ND, Cohen EA, Naylor CD, Fremes SE; Radial Artery Patency Study Investigators. A randomized comparison of radial-artery and saphenous vein coronary bypass grafts. N Engl J Med 2004; 351: $2302-2309$

70. Nakajima H, Kobayashi J, Funatsu T, Shimahara Y, Kawamura M,
Kawamura A, et al. Predictive factors for the intermediate-term patency of arterial grafts in aorta no-touch off-pump coronary revascularization. Eur J Cardiothorac Surg 2007; 32: 711-717.

71. Desai ND, Naylor CD, Kiss A, Cohen EA, Feder-Elituv R, Miwa S, et al. Impact of patient and target-vessel characteristics on arterial and venous bypass graft patency: Insight from a randomized trial. Circulation 2007; 115: 684-691.

72. Singh SK, Desai ND, Petroff SD, Deb S, Cohen EA, Radhakrishnan $\mathrm{S}$, et al. The impact of diabetic status on coronary artery graft patency: Insights from the radial artery patency study. Circulation 2008; 118(Suppl 1): S222-S225

73. Buxton BF, Raman JS, Ruengsakulrach P, Gordon I, Rosalion A, Bellomo R, et al. Radial artery patency and clinical outcomes: Fiveyear interim results of a randomized trial. J Thorac Cardiovasc Surg 2003; 125: 1363-1371.

74. Collins P, Webb CM, Chong CF, Moat NE; Radial Artery Versus Saphenous Vein Patency (RSVP) Trial Investigators. Radial artery versus saphenous vein patency randomized trial: Five-year angiographic follow-up. Circulation 2008; 117: 2859-2864.

75. Muneretto C, Negri A, Manfredi J, Terrini A, Rodella G, ELQarra S, et al. Safety and usefulness of composite grafts for total arterial myocardial revascularization: A prospective randomized evaluation. J Thorac Cardiovasc Surg 2003; 125: 826-835.

76. Damgaard S, Wetterslev J, Lund JT, Lilleør NB, Perko MJ, Kelbæk $\mathrm{H}$, et al. One-year results of total arterial revascularization vs conventional coronary surgery: CARRPO trial. Eur Heart J 2009; 30: $1005-$ 1011. 